\title{
Role of Doctors in the Criminal Proceedings of Bangladesh with Special Reference to Women's Access to Justice
}

\author{
Dr. Md Abdur Rahim Mia, Associate Professor, \\ Department of Law, Rajshahi University, Rajshahi, Bangladesh,
}

\begin{abstract}
Doctors play a great role in criminal justice system, because a medical report is very important document in most of the criminal cases, but sometimes it becomes a major obstacle in acquiring justice. Doctor's reluctance to appear in the court, false report given by doctors or corruption may hinder women's access to justice. Doctors also face different challenges in case of medical check up and forensic examination which affect victims' rights under the criminal justice framework. This article attempts to disclose the role of doctors under criminal proceedings and different obstacles as they face in Bangladesh, which may affect women victims in criminal proceedings.
\end{abstract}

Key Words: Women victims, criminal proceedings, forensic examination, doctor, medical report, perpetrators, access to justice, autopsy.

\section{Introduction}

Criminal Proceedings is based on different activities of court proceedings, functions of police and prosecutions such as filing of a case, investigations, arrest, framing of charge, trial, conviction or acquittal etc. ${ }^{1}$ This procedure is followed in all criminal cases in Bangladesh. Medical evidence plays an important role in the administration of justice. Medical report given by a doctor is an essential document in most of the criminal cases, but it often becomes a major obstacle in acquiring justice. This is particularly due to the doctors' reluctance to appear in the court and false reports given by doctors' according to victims' desire or pressure. Sometimes perpetrators put pressure on doctors to produce false reports. Doctors face different obstacles in case of medical check up and forensic examination of victim, which can hamper the whole legal procedure. The right to get legal remedy through court proceedings causes hardship for women. There are a lot of formalities for criminal proceedings. The ordinary people, in particular, women do not have access to criminal proceedings. ${ }^{2}$ Due to various reasons, women victims are not always able to seek judicial remedy in Bangladesh. ${ }^{3}$ The question of victimization of women and their status in the criminal proceedings cannot be dealt with efficiently without taking into account some fundamental problems, which weaken women more than any other victims when they are confronted with the complexity of the criminal proceedings. Police, doctors, lawyers and Judges can play effective role to protect women's human rights, but in most of the cases, anyone of them may hinder women's access to justice. The purpose of this study is to disclose the role of doctors in ensuring justice to women victims and different obstacles as they face in Bangladesh on legal courses along with weaknesses of criminal proceedings in relation to women victims of violence. This article has been mostly developed from an interview in June 2010 to September 2010 at Rajshahi Court of 25 women victims, among them 14 took admission in Rajshahi One Stop Crisis Centre (OCC) prior to their administering of criminal cases at the said Court $^{4}$ and Rajshahi Medical College Hospital of 15 doctors. The findings in this article are based on over-all perceptions gathered from face to face interview.

\section{Importance Of Doctor's Report In The Criminal Proceedings Of Bangladesh}

The importance of medical evidence is to lend corroboration to other types of evidences. ${ }^{5}$ It proves that the injuries were possible in the manner alleged. ${ }^{6}$ But, in case of hurt, rape, death and acid throwing, chemical examination and the report of doctors are essential for criminal adjudication. In case of rape, the medical examination is supposed to be completed as soon as possible after the occurrence. ${ }^{7}$ When the victim appears before the doctor, the doctor should give report and certificate about the occurrence. ${ }^{8}$ In a medical examination of rape victim, the doctor first takes the history of the incident from the victim and follows with an examination of the injuries. Where there is other reliable evidence to prove the offence, medical evidence is not indispensable. A seal is given in the medical report and the doctor in whose name seal has been given, has to be produced in the court for confirming the report. The evidence of the doctor is another reason for delay in rape cases. $^{9}$

Statement given by a doctor is important evidence in Bangladesh. According to the Code of Criminal Procedure, 1998, the deposition of a doctor or other medical witness, taken and attested by a Magistrate in the presence of the accused may be given in evidence in any inquiry, trial or other proceeding under this Code. ${ }^{10}$ In 
a criminal proceeding, the report of a post-mortem examination is used as evidence, even if the doctor who made the report is dead or is incapable of giving evidence or is beyond the limits of Bangladesh and his attendance cannot be procured without an amount of delay, expense or inconvenience which, under the circumstances of the case, would be unreasonable, such report may be used as evidence. ${ }^{11}$ On the other hand, any document purporting to be a report under the hand of any chemical examiner or assistant chemical examiner to Government or any serologist, handwriting expert, finger print expert or fire-arm expert appointed by the Government is used as evidence in any inquiry, trial or other proceeding under this Code. ${ }^{12}$ Doctor plays an important role in criminal proceedings as his determinations and court testimony may affect criminal liability, ranging from different degrees of homicide, to responsibility for accidental deaths, inheritance rights or life insurance benefits. The doctor serves both the administration of justice and the public health interests of the community. Doctors are appointed by a governmental body and operate under statutes that give them investigational jurisdiction in criminal cases. Doctors in their pathological reports must make a determination of the manner of death, i.e., whether the death was a homicide, an accident, or a suicide and must make determination of the manner of assault. All the findings are thoroughly documented in a medical report and in auxiliary documentation. The medical report lists all the medical diagnoses evident in the case and the actual cause of death is then determined. ${ }^{13}$ Sometimes, in criminal cases, a defendant may allege certain circumstances of death of the deceased victim or assault of the victim and the doctors need to determine whether this explanation fits or does not fit the nature, pattern, and extent of injuries and the findings at the place of occurrence. In modern times, forensic science has become an integral part of the process of crime detection and new aspects of forensics are being developed along with technology to support them. ${ }^{14}$ In the forensic examination, doctors also see incidental cases of very challenging deaths, such as battered or shaken children alleged to have sustained accidental fall injuries, dismembered or decomposed homicide victims, masked suicides, unusual causes of death such as water intoxication or exotic drugs, rare genetic diseases, and apparently unexplained deaths in medical facilities. ${ }^{15}$ Every doctor in pathological service has an implicit duty of presenting the forensic findings in a clear and bias-free manner. In our adversarial system of trial procedure, the medical examiner must be the standard bearer of unvarnished truth. ${ }^{16}$

\section{Victim's Perception About The Contribution Of Doctors Regarding The Violation Of Their Rights In The Criminal Proceedings}

25 women litigants were interviewed on their perceptions and experiences of going to police stations, going to doctors, going to court, being in court during trial. The women represented a variety of backgrounds, rural, poor, middle class and upper-middle class as well as a cross section of experience with violence i.e rape, domestic violence, dowry etc. From the interviews with the women litigants, it was apparent that they were very frustrated with the long cumbersome legal process. Many were reluctant to pursue their cases as they were intimated and threatened by their opponents. Some women were extremely apprehensive of the court, law and police. They were fearful of the legal process and felt that they had no access to the legal system. They also expressed that they faced various difficulties to come out from their home and to make a complaint against male family members or others due to lack of knowledge and confidence, financial dependence on others, communication and transport problems, discouraging social norms etc. One poor victim, named Jahanara Begum ${ }^{17}$ said, 'The court is not for the powerless people like me, police, lawyers, doctors, everyone wants money only, they don't try to understand my sufferings.'

Among 25 victims, 20 victims took medical treatment from several hospitals. For large number of patients, shortage of beds, insufficiency of medicine and instruments the patients are deprived from medical care. ${ }^{18}$ The negligence of hospital administrators, nurses, behavior of Aya (Nurse assistant) affects patients' rights. ${ }^{19}$ Doctors like the police also consider victims as 'bad'. Most of the doctors think that the majority victims are habituated to rape. ${ }^{20}$ In the court proceedings, the certificate given by the doctor is strong evidence of the incidence. ${ }^{21}$ Sometimes doctors give false certificate in favour of the accused. ${ }^{22}$ Police and criminals have a tendency to influence medical reports to fabricate those in their favour to cover up their misdeeds. ${ }^{23}$ According to a rape victim, ${ }^{24}$ medical report of a doctor in case of criminal case means monetary corruption of a doctor. She also added that her incident was true, but doctor gave certificate that there was no alamat (symbol) for rape. Delay and corruption in medical tests cause many legal problems. There are many incidents in Bangladesh where the perpetrators guilt could not be proved due to false or defective medical report. Most of the medical reports given by the doctors are defective. Sometimes doctors are not available, whilst the victim is taken to the hospital for medical examination. Therefore women are being deprived of getting justice. Sometimes doctors are rude to their victims. Victims were asked about the behaviours of the doctors. Their responses are given below: 
Table 1

Behaviour of doctors faced by women victims

\begin{tabular}{|l|l|}
\hline Nature & Percentage \\
\hline Good & $20 \%$ \\
\hline Discourteous & $40 \%$ \\
\hline Oppressed & $40 \%$ \\
\hline
\end{tabular}

Table 1 shows that $20 \%$ women victims faced good behaviour, $40 \%$ discourteous, and $40 \%$ oppressed or despicable behaviour from doctors. Therefore only $20 \%$ women victims were happy and rest of the $80 \%$ women victims were unhappy with the behaviour of doctors. Victims were asked about the role of doctors in case of giving medical report. 20 victims answered according to the following table:

Table 2

Role of doctors in case of giving medical report

\begin{tabular}{|l|l|}
\hline Role of the doctors & Percentage \\
\hline Given timely and appropriately & $20 \%$ \\
\hline Not given timely and appropriately & $20 \%$ \\
\hline Demanded bribes and taken it & $45 \%$ \\
\hline Demanded bribes and given biased report for not getting it & $15 \%$ \\
\hline
\end{tabular}

According to table 2, 20\% victims said that doctor gave medical report timely and appropriately, $20 \%$ victims said that doctor did not give medical report timely and appropriately, $45 \%$ victims confessed that doctor demanded and took bribe from them, only $12 \%$ victims said that doctor demanded bribe from them and gave biased report for not getting it. 14 victims had been admitted to One Stop Crisis Centre (OCC), Rajshahi. They experienced different types of behaviors from doctors and nurses.

Table 3

Behaviour faced by women victims from doctors and nurses into the OCC, Rajshahi

\begin{tabular}{|l|l|}
\hline Nature & Percentage \\
\hline Sincere & $42 \%$ \\
\hline Discourteous & $16 \%$ \\
\hline Terrifying & $42 \%$ \\
\hline
\end{tabular}

Table 3 shows that $42 \%$ women victims faced cordial behaviour, $16 \%$ discourteous, and $42 \%$ oppressed behaviour from doctors and nurses of the OCC, Rajshahi. Lack of attention and attendance of the doctors is another cause of the violation of women rights in OCC.

\subsection{Male Doctor for Medical Check-up and Forensic Examination}

In absence of female doctors, most of the women victims received treatment from male doctors. The experience that the victim faces when undertaking medical check-up is most unpleasant. The Forensic Department is in charge of the full physical examination. Male physicians in the Sexual Assault Examination Unit examine the victim under the presence of a nursing assistant. According to Naripokkho ${ }^{25}, 23$ of 29 rape victims on which it conducted a survey refused to be tested by male. ${ }^{26}$ The presence of the male doctor as an examiner is itself a trauma for the victim, especially in a country where social values and religion play an important role in their lives. ${ }^{27}$ Most of the victims do not allow male doctors to do the test. ${ }^{28}$ Most of the victims of rape cases are not interested to do test due to the lack of specialist doctors. Absence of female doctors in the forensic department put the woman victim in a vulnerable position. There are only two female doctors in the forensic department in total 13 medical college hospitals in Bangladesh. ${ }^{29}$ According to one doctor, ${ }^{30}$ female doctors are not interested to come to this department. As a result male doctors have to be there to perform this duty in presence of either a nurse or aya. ${ }^{31}$

A ten years old girl on her way to school was raped by a young man in an under -construction building. She was rescued by a woman and brought to hospital. At hospital earlier the girl's mother vehemently objected to the medical tests by male doctors. Later she argued to do medical test of her daughter but legal proceedings is delayed as a consequence. One of the several key reasons for the delayed process is the reluctance of women victims against being tested by male doctors. Female doctors are terribly in short supply to perform the job. Since the rape victims in Bangladesh are all women they feel shy and some believes it goes against religious practices to undress before male doctors. Female doctors feel discouraged to do the forensic job to avoid the hassle of standing as witness in rape cases. In Bangladesh, such cases drag for years and the witnesses are to 
appear in court on their own expenses. Trial dates change a lot causing more problems to the witnesses. In addition, there are risks of attacks and reprisals by the accused. The trial hassle is a key factor that deters female doctors from joining the forensic job. In our country concerned doctors are to appear in court as witnesses. In many other countries, the doctors need not to go to court. They only send the reports to court. ${ }^{32}$

$80 \%$ women victims said that they completed their check up by male doctors and only $20 \%$ made their check up by female doctors. A research conducted by ' $F O W S I A{ }^{33}$ shows that among the 86 cases, $70 \%$ patients are tested by male doctors and $30 \%$ cases by female doctor. ${ }^{34}$ Due to shortage of female doctors, some victims of such crimes are bound to be tested by male doctors for filing the case, but most of the victims avoid them for which they are once again victimized under the criminal justice system.

\subsubsection{Post Mortem Report}

After death of a victim woman, the dead body is sent to the forensic department for a post mortem report. ${ }^{35}$ As the day light is necessary to perform the autopsy, it is usually conducted during the office hours by the forensic doctor who is in roster duty at the autopsy room, assisted by a hospital sweeper. During autopsy, the first task is to externally examine the body and locate signs of distress. The aim of this external examination is to determine if the case is one of suicide, murder, accident or disease. ${ }^{36}$ In fact the sweeper is the one who mainly handle the body. In most of the cases this sweeper and the forensic doctor are male. In many cases due to religious feelings, love and affection the process of post mortem face barriers. The accurate completion of postmortems and the preparation of proper, unbiased and non-conflicting reports are very important for identifying the genuine causes of death. In most of the cases, the post-mortem reports are not accurately written and conflict with the statements of witnesses. ${ }^{37}$

\subsection{Reluctance of Doctors}

\section{Obstacles Of Doctors In The Criminal Proceedings}

Doctor's reluctance to appear in the court is the major obstacle in acquiring justice. The major causes of such unwillingness, as have been identified by doctors are:

(i) Sense of insecurity in case of appearing in the court,

(ii) No incentive for the time spent while involved in the case and

(iii) Reluctance of the courts to recognize them as 'expert'.

Most of the doctors were not interested to do forensic test or to give test certificate for some obstacles. The doctors identified the reasons of unwillingness for the forensic test during the time of interview. These are: there is no allowance for forensic test; doctors get only 5 taka for going to the court as a witness; doctors face unnecessary question of opposite advocate into the courtroom; doctors feel insecure for being a witness; many women do not allow male doctor for forensic test; and influential people or politicians sometimes pressure them to make false or weak report. In the forensic test doctors do not agree to touch the patient without the permission of the Magistrate. Some formalities have to be followed before the forensic test. These are: (i) A passport size picture of the victim must be attached by the Commanding Officer (OC) of thana. Sometimes it creates problem and test gets late, as such evidence can be destroyed; and (ii) Forensic test report needs a stamp. It may not be served timely by the hospital authority. Radiology and Pathology test sometimes take time. A doctor has to make not only the list of forensic test but also has to perform various duties. Sometimes he has to stay long day for hearing into the court. There is no waiting room in the court; it is an embarrassing situation for the doctor. There are very few doctors in a hospital who are specialist in the forensic test. Sometimes they feel unsecured for the pressure of powerful persons of the society. For these reasons, doctors do not want to do forensic work.

\subsection{Different Kinds of Pressure}

Under criminal proceedings, it is the duty of a doctor to give appropriate medical certificate. Most of the doctors said that they felt various pressures for not giving medical report to the victims. $86 \%$ doctors faced political pressure, pressures of influential people, threat of opposite party, victim's offer of bribe for giving her false or strong certificate, load of work etc. But only $13.33 \%$ said that they had no pressure in dealing the victims. Doctors were also asked whether police pressured them or not. $60 \%$ doctors answered that police pressured them for giving weak report or not giving appropriate medical report to victims. Only $40 \%$ said that police did not pressure them for such kind of work. In case of Doli from Chuadanga, who was a victim of gang rape, the perpetrators put pressure on the doctor to produce a false report stating that Doli was not raped. But a second medical test, conducted in khulna identified evidences of rape. Doli's case is not a unique one- there are many such incidents where the perpetrators could not be proven guilty due to false medical report. ${ }^{38}$ 


\subsection{Difficulties of Medical Check up}

When women victims come to the doctor for medical check up, there are some impediments for doing this job, which can deprive women from enjoying their rights of medical care. Doctors were asked about these impediments. Their responses are given below:

Table 4

Impediments of doctors for medical check up or treatment

\begin{tabular}{|l|l|}
\hline Types of Impediments & Percentage \\
\hline Large number of patients & $100 \%$ \\
\hline Shortage of bed in the hospital & $66.67 \%$ \\
\hline Lack of medicine & $53.33 \%$ \\
\hline Inadequate medical instruments & $66.67 \%$ \\
\hline Shortage of women doctors & $60 \%$ \\
\hline Negligence of hospital administration & $33.33 \%$ \\
\hline Reluctance of nurses and office staffs of hospital & $66.67 \%$ \\
\hline Negative outlook of doctors upon women victims & $13.33 \%$ \\
\hline Formalities before forensic test & $66.67 \%$ \\
\hline
\end{tabular}

Table 4 shows that most of the doctors confessed that they did not properly serve victims for some impediments.

\subsection{Impediments of Forensic Test}

The forensic doctor first scrutinizes the woman's body externally from head to toe. The signs which the doctor looks for are scratches, bruises, whether the breasts have been manhandled, the condition of pubic hair, vaginal/perennial tears, bleeding etc. The doctor also observes the woman for signs of psychological trauma. Then a high vaginal swab is taken. For a rape case, the medical examination has to be done within 24 hours of the incident. ${ }^{39}$ In the Radiology Department x-rays are taken and the age of the woman is assessed by looking at the union of the joints in her ankles, elbows and knees. Tests for blood grouping, the presence/absence of spermatozoa and sexually transmitted diseases are conducted at the Pathology laboratory. ${ }^{40}$ The most valuable part of rape victim under criminal proceedings is forensic test report. Doctors were also asked about the impediments of forensic test. Their responses are given below:

Table 5

Impediments of forensic test

\begin{tabular}{|l|l|}
\hline Types of Impediments & Percentage \\
\hline Shortage of women doctors or expert doctors & 80 \\
\hline Permission of Magistrate before forensic test & 46.67 \\
\hline Collection of photograph before forensic test & 73.33 \\
\hline Delay in Radiology and Pathology report & 86.66 \\
\hline Only one Forensic Labratory in Dhaka & 86.66 \\
\hline No remuneration & 66.67 \\
\hline
\end{tabular}

According to table 5, it is clear that said grounds affect the victims and doctors did not work and serve appropriate report timely. There are also some deficiencies in the forensic examination, which may violate women rights, such as, lack of adequate staff, or lack of exposure to other biochemical laboratories; lack of air conditioning atmosphere for collecting appropriate evidence; the Sexual Assault Examination Unit does not have adequate privacy; lack of disposable gown to be worn by the woman being tested etc. ${ }^{41}$ Such impediments result in failure to prove validity of doctor's report and thus, hampers the whole legal procedure.

\section{Doctor's Argument In Favour Of Their Women-Friendly Attitude}

Doctors were asked about the attitudes of doctors and nurses when victims came to them for medical treatment or check up. Their Responses are given below:

Table 6

Behaviour of doctors and nurses

\begin{tabular}{|l|l|}
\hline Types & Percentage \\
\hline Good & $73.33 \%$ \\
\hline Terrible & $6.67 \%$ \\
\hline Non-co operational & $20 \%$ \\
\hline
\end{tabular}


According to the doctors' perception, $26.67 \%$ victims faced terrific and non-cooperational behaviour from doctors and nurses and $73.33 \%$ women victims enjoyed good behaviour from them. But according to the victim's view, table 1 shows that only $20 \%$ women victims faced good behaviour, $80 \%$ faced discourteous, oppressed and despicable behaviour from doctors. Victims were asked about the role of doctors in case of giving medical report. 20 victims answered. Among them, 60\% said that doctors demanded bribe and $15 \%$ said that doctors had given biased report for not getting bribe. 14 victims had been admitted to One Stop Crisis Centre, Rajshahi. They experienced different types of behaviour from doctors and nurses. According to table 3, 42\% women victims faced cordial behaviors, $16 \%$ discourteous, and $42 \%$ oppressed or terrible behaviour from doctors and nurses of the OCC, Rajshahi.

\section{Corruption Of Doctors In The Criminal Proceedings}

Corruption is the vital factor for violation of women rights under a criminal proceeding. ${ }^{42}$ A medical officer at a hospital can issue a medico-legal certificate which is invaluable for the woman if the case goes to court. It states the nature of the injury in detail and by whom the injury was caused here, all cases of accidents, poisoning and burns. ${ }^{43}$ But giving of certificate on payment to a victim for determination of age or nature of offence has become a regular matter of the doctor of government hospital. ${ }^{44}$ In most cases, admission of patient to the hospital gives opportunity to the authority to earn money in unethical way. As mental and psychological torture has not been addressed under the Women and Children Repression Act, 2000, doctors are often lured by the greed of making good earnings through providing false and fabricated medical certificates confirming allegations of causing simple or grievous hurt. ${ }^{45}$ A Survey conducted by the Transparency International of Bangladesh found that 48 percent admitted to government hospital by alternative methods including 56 per cent paid money, 22 per cent used influence, and 18 per cent sought help from hospital staff .This survey also showed that doctors were most corrupted followed by hospital staff. ${ }^{46}$ An Editorial of English daily commented that Bangladesh experiences show "more than their number, corruption and lack of integrity of the doctors are perhaps, more important factors that explain the poor quality of services at the government run hospitals". ${ }^{47}$ The corruption starts from appointment of a peon up to the highest post. Since they get appointment with high money, so, their first priority is to be reimbursed. At the result health service seeker become victim of unexpected harassment. They have to pay extra money which may not be possible to get service in public hospitals. There is a circle of broker for collecting corrupted money. Victims do not take legal action for possibility not to get proper remedy. ${ }^{48}$ Corruption in delivery of medicine, service by doctors and nurses, bribery to get bad in hospital are common form of corruption. Victims have to extra pay for government medicine, seat in hospital and other equipments. Doctors have collaboration with private Diagnostic centre and private clinic. ${ }^{49}$ It is also known that doctors often suggest that the patient go to a diagnostic center for $\mathrm{x}$-ray, pathological test and the doctors receive some commissions. The problem is that only the doctor can decide what needs to be done. If this goes well, the patient does not complain and if it does not only then the allegation of corruption surfaces.

One victim ${ }^{50}$ said,

'She was seriously injured in a road accident, but there was no doctor in the emergency. As the condition was serious, she approached a doctor in OT, who demanded money before anything could be done. She paid the money and got admitted but after a few days she was discharged because she had no money to pay.'

Sometimes doctors of Governmental Hospital refer victims to private clinic or refer to the consultant. ${ }^{51}$ Common complaints against public hospitals include the apathy of doctors and nurses regarding their job and negligent attitude towards the patients. There are allegations of negligence, absence in the workplaces, misbehaving with patients, tendency to ask for 'commission' and general corruption. ${ }^{52}$ As a result people prefer private hospitals although only a few can afford them. Corruption does not only occur in the withdrawal of cases, but also in the conduct of autopsies. After death, correctly prepared autopsy reports are essential to understand and confirm the causes of death and thus ensure the correct punishment. However, Odhikar ${ }^{53}$ has observed that in 2011 this has not always been the case. ${ }^{54}$ At Noria of Shariatpur district, fourteen year old Hena Akhter was raped by forty year old Mahbub on January 30, 2011. Due to this, a village arbitration decided that she must be given 100 lashes. She fell unconscious after nearly 80 lashes on January 31, 2011. She was fatally injured and died in Naria Health Complex. The first autopsy report on Hena had stated that there was 'no sign of hurt' on the body. The second autopsy report states that Hena died due to hemorrhage as she was injured by blunt weapons. Eight marks of injuries had been indicated in the new post-mortem report and yet the previous report has mentioned 'no sign of hurt'. The High Court Division stated that the first post-mortem report was prepared deliberately by officers to make justice fail. ${ }^{55}$ The High Court directed the government to prosecute four doctors of Shariatpur, for preparing fallacious autopsy report, because the doctor's negligence in preparing the autopsy report is against medical ethics. ${ }^{56}$ 


\section{Analysis And Suggestion}

A serious problem that unfolds during conduction of criminal cases, particularly women repression cases is that in most cases male doctors medically examine violated women. The reality is that most women feel shy and reluctant to be examined by male doctors. They can't be free to speak out the exact condition of their incident to a male doctor, even after being violated or repressed. ${ }^{57}$ Consequently, the merit of litigation is destroyed during the medical tests. ${ }^{58}$ Worse, many women don't go for medical examination only due to absence of a female doctor in the clinic or the government hospitals. Sometimes doctors do not give the certificates in right time and sometimes they do not give correct certificates and for this the investigation is hampered. Doctors are often lured by the greed of making good earnings through providing false and fabricated medical reports. ${ }^{59}$ They are not even interested to abide by the law to give the certificates to the complainants or the victims. Sometimes the doctors show their reluctance to give medical certificates, as they have to face much harassment to provide witness of any case at the court. It is clear from the above discussion that corruption of doctors is the prime obstacle in ensuring women rights in criminal justice in Bangladesh. Therefore, it should be the first attempt of the concerned stakeholder to take initiative to eradicate corruption in health service to ensure a minimum standard of public health service. The regulatory framework for monitoring health services delivery is weak. There are 45 laws related to various aspects of heath like Epidemic Disease Act 1897, Prevention of Malaria Ordinance 1978, laws related to quality of food, quality of drugs etc. It is the duty of the Ministry of Heath to supervise and monitor the health activities of their respective areas, they seldom do this. ${ }^{60}$ The Bangladesh Medical and Dental Council (BMDC), established under the Medical and Dental Council Act of 1980 is empowered to look after public interest by maintaining proper standards of services and education. It has the authority to take disciplinary actions, including temporary suspension or permanent removal of the practitioner from the register for misconducts like issuing false certificates, disregard of personal responsibility to patients etc. But due to the absence of a monitoring system on the activities of practitioners, it is very difficult to implement, and there is no such evidence till now of a practitioner's name being removed from the register. ${ }^{61}$ Bangladesh has only 18 doctors and 5 nurses per 100,000 people. As remuneration of public hospitals is very low and many of those doctors and nurses try to find job in private clinics, no wonder that public hospitals experience shortage of medical personnel. Therefore, when a patient comes for the medical help to the public facilities, very often it is the case that hospital has no specialists with appropriate skills or knowledge, or there is a lack of staff which can give very basic help. ${ }^{62}$ For these above grounds, the rights of women victims are violated by doctors under the criminal justice process in Bangladesh. To ensure women's access to justice the following steps/measures should be taken:

Government should appoint at least one female doctor to look after women repression cases in every governmental hospital. Also, adequate equipments and forensic facility must exist in all district hospitals of the country so that proper information about the physical condition of violated women can be expeditiously and effectively collected by the on-duty female doctors of the medical hospitals. Moreover, the appointed doctors should also be mentally prepared to provide with emergency facilities to the women who come to them with wounds or physical injuries following repression. Law should be enacted by making provisions to take disciplinary and punitive action against the doctors who are liable for delay in filing forensic report and also for filing false forensic report. The salary, wages of the doctor for test should be increased. Female doctor should be appointed at forensic department. Forensic science institute should be made with forensic expert. Doctors should be appointed for full time. Special training of doctors and nurses should be arranged. Specific punishment should be brought for doctors who make false medical report. Medical records should reflect objective information and comments about patients and should not include derogatory or unsubstantiated observations or opinions. In summary, medical records should be accurate, objective and contain information recorded at the time the treatment is given or the observations are made. The report prepared by doctor for legal purpose should be specific and well narrated. The number of trained professional doctors should be increased. The forensic labs should be modernized and Forensic Institute should be established to provide proper knowledge and adequate training on forensic science. A one-stop crisis centre should provide with encounter of the victim's crisis to all the medical coverage, legal actions and in providing medical reports etc. The systemic corruption should be contained by making the system transparent and encouraging work in outlying areas through reward. The post mortem should be conducted by combined specialists and necessary action should be taken in order to promptly gather the medical examiner, police and legal representative. A Medic Legal Advisory Committee should be formed in order to examine the post mortem report and other medico legal tests. The medical personnel should be trained with regards to medico-legal materials.

\section{Conclusion}

According to Bangladesh Constitution, everyone has the right to life, liberty and security of person, ${ }^{63}$ no one shall be subjected to torture or to cruel, inhuman or degrading treatment or punishment ${ }^{64}$ and all are equal before the law and are entitled without any discrimination to equal protection of law. ${ }^{65}$ The duty of the 
court in a criminal proceeding is not only to adjudicate upon the allegations made against the accused, but also to see that the safety of the informants or complainants is not jeopardized because of their involvement in the proceeding. Evidence given by doctors or health care workers may play a crucial role in assisting the court in deciding whether accused persons should be found guilty or not guilty in criminal cases. There are five different stakeholders that are involved in criminal process, such as, (i) victims, (ii) police, (iii) lawyers, (iv) judicial officers and (v) doctors. If all stakeholders perform their duties honestly and sincerely, justice is sure to be served to the victims and accused. The first task of every case relating to women is to confront the primary crisis and report to the law-enforcing agency. They will then visit the spot, collect evidences and perform a medical test, if necessary on the victim by a doctor. Delay and corruption in medical tests cause legal problems. Corruption has been identified in every entity of the criminal justice system and as it makes the law ineffective, it has a very demoralizing effect on women. Sometimes the doctors show their reluctance to give medical certificates, as they have to face much harassment to provide witness of any case at the court. It is deplorable to say that the criminal justice system of Bangladesh is not friendly in its treatment towards women. Lack of medical facilities, low remuneration of governmental doctor, less number of female doctors, unwillingness of female doctors to work in forensic department, insensitive attitudes of doctors affect women victims in criminal proceedings.

\section{References:}

[1] Hannan, M Abdul. 2009. Human Rights of the Accused in the Criminal Process', Gurgaon, India, MADHAV BOOKS, p.1; UdDin, M Faiz and Hannan, M Abdul. 2000. Protection of Human Rights in Criminal Justice: Bangladesh Perspective, Research Project 1998, Rajshahi University, Bangladesh, p.1; Munir, Shaheen Akhter. 2006. An Annual Research Report on Violence Against Women in Bangladesh 2005, Dhaka, BNWLA, p. 77

[2] Ali, Mohammad Yusuf. 2006. 'Easy access to justice: Overcoming the Problems', The Daily Star, 4 March 2006, p.18

[3] Blessy, Jain. 1990. Constitutional Law', London, HLT Publication, p.12-13

[4] It may be worth mentioning that the researcher was not allowed to take interviews of women victims admitted in the OCC of Rajshahi Medical College Hospital. The researcher went to the OCC for three consecutive days but the In-Charge said that a written permission from the Project Director of Multi-Sectoral Programme on Violence Against Women of the Ministry of Women \& Children Affairs is needed to collect any data or for sit in interview of women victims admitted at OCC.

[5] Mofazzal Alias Md. Mofazzal Hossain and another v. The State, 7 BLD, HCD, 1987, 406

[6] BNWLA, 1999. A Research on Rape and Burden of Proof, Dhaka, Bangladesh National Women Lawyers Association (BNWLA), p.87

[7] Section 32(i), The Nari O Shishu Nirjaton Damon Ain, 2000

[8] Section 29, The Acid Crime Prevention Act, 2002

[9] Naomi, Sharin Shajahan. 2009. The Legal Challenges on the way to Judicial Remedy in Rape Cases: The Role of Human Rights and Legal Services Programme of BRAC, BRAC Research Report, Dhaka, April 2009

[10] Section 509 (i), The Code of Criminal Procedure, 1898

[11] Section 509 A, Ibid

[12] Section 510, Ibid

[13] Joshua, A. Perper. 'The Medical Examiner and the Criminal Justice System: A Portrait of the Medical Examiner', available at http://articles.sun-sentinel.com/2011-02-04/news/fl-jpcol-medical-examiner-perper-020620110204_1_medical-examinersaccidental-death-autopsy-report/2, last accessed on 7 August 2012

[14] Hossain, Anika. 'The Science Behind

Crime Detection', available at http://www.thedailystar.net/magazine/2011/07/04/crime.htm, accessed on 7 August 2012

[15] Ibid.

[16] Ibid

[17] State Vs Kajimuddin (2003), Case no 201/2003, GR No- 5/2003, Nari O Shishu Nirjaton Damon Tribunal, Rajshahi.

[18] Interview with a Doctor.

[19] Ibid

[20] Interview with a Woman Victim.

[21] Section 23, The Nari O Shishu Nirjaton Damon Ain, 2000; Section 20, The Acid Crime Prevention Act, 2002.

[22] See Camelia Murder Case, at Munir, Shaheen Akhter. 2006. An Annual Research Report on Violence Against Women in Bangladesh 2005, Dhaka, BNWLA, p.33

[23] Jahan, Asma Akhter. 2005. Women Violence in Bangladesh and Legal Framework: Role of Law Implementing Institutions, Dhaka, FOUSIA, p. 66.

[24] Interview with a rape victim, named Zaheda Khatun, Case no-486/2003, Nari O Shishu Nirjaton Damon Tribunal, Rajshahi.

[25] An Human Rights Based NGO of Bangladesh

[26] Nahar, Kamrun. 2004. 'Medical test of rape victims More female doctors needed', The Daily Star, 15 February 2004, p. 23

[27] Baseline Report on Violence Against Women in Bangladesh Prepared by Naripokkho and Bangladesh Mahila Parishad and coordinated by IWRAW Asia Pacific, Dhaka, p.56

[28] BNWLA, 2002. Violence against Women in Bangladesh', Dhaka. BNWLA, p. 91

[29] Found from Interview with Doctors.

[30] Interview with Dr. Rosy Ara Khatun, Medical Officer, Medical Sub-dipo, Divisional Office, Rajshahi.

[31] Baseline Report on Violence Against Women in Bangladesh Prepared by Naripokkho and Bangladesh Mahila Parishad and coordinated by IWRAW Asia Pacific, p.56

[32] Nahar, Kamrun (2004), Op.cit, p. 23

[33] Forum on Women in Security and International Affairs.

[34] Jahan, Asma Akhter. 2005. Women Violence in Bangladesh and Legal Framework: Role of Law Implementing Institutions, Dhaka, FOUSIA, p.66 
[35] For post mortem of any dead body, two things are required from the police: i) the Inquest Report, which includes the name, address and age of the woman, how the body was found by the police and a detailed description of the case along with any other evidence that may have been collected; and ii) a memo, which includes the request to the forensic department to conduct a forensic examination and identify the cause of death. See for more details: Baseline Report on Violence Against Women in Bangladesh Prepared by Naripokkho and Bangladesh Mahila Parishad and coordinated by IWRAW Asia Pacific, p.36

[36] Baseline Report on Violence Against Women in Bangladesh Prepared by Naripokkho and Bangladesh Mahila Parishad and coordinated by IWRAW Asia Pacific, p.36

[37] ODHIKAR, HUMAN RIGHTS REPORT 2011, Odhikar Report on Bangladesh, 7 January 2012

[38] Moslem, Sima. 2004. DHARSHAN CHITRA: analysis of Rape victims in Bangladesh (2002-2004), Dhaka, Bangladesh Mahila Parishad, p.76

[39] Baseline Report on Violence Against Women in Bangladesh Prepared by Naripokkho and Bangladesh Mahila Parishad and coordinated by IWRAW Asia Pacific, p.34

[40] Ibid., p.36

[41] Ibid.

[42] 'Understaffed health service', The Daily Star, Editorial Page, 1 March 2010

[43] Shedde, Meenakshi. 2002. One-stop crisis centre for women', available at http://articles.timesofindia.indiatimes.com/2002-0308/mumbai/27110207_1_hospital-staff-domestic-abuse-city-hospitals/2, accessed on 03 May 2011

[44] Interview with a Women Victim, who admitted into OCC.

[45] BNWLA, 2010. Violence against Women in Bangladesh 2008-2009, Dhaka, BNWLA, p.44

[46] Alam, Md. Ashraful. 2012. 'A cross examination of gross corruption in public health service', The Daily Star, 4 August 2012

[47] Ibid

[48] Ibid

[49] Ibid

[50] Interview with a Victim of Rajshahi Court in the name of anonymity.

[51] Kamol, Ershad. 2009. What Healthcare can be, available at www.thedailystar.net/magazine/2009/10/01/cover.htm, accessed on 07 August 2012

[52] Ibid

[53] An Human Rights Based NGO of Bangladesh

[54] HUMAN RIGHTS REPORT 2011, Odhikar Report on Bangladesh, 7 January 2012

[55] Ibid; The Daily Ittefaq, 10 February 2011

[56] Alam, Md. Ashraful. 2012. 'A cross examination of gross corruption in public health service', The Daily Star, 4 August 2012; Sarkar, Ashutosh. 'Girl Whipped to Death Prosecute 4 doctors', available at http://www.thedailystar.net/newDesign/newsdetails.php?nid=179561, accessed on 6 August12; 'Girl whipped to death, doctors said it was suicide', available at http://news.asiaone.com/News/AsiaOne+News/Crime/Story/A1Story20110329-270667.html, accessed on 7 August 2011

[57] BNWLA, 2002. Violence against Women in Bangladesh 2001, Dhaka, BNWLA, p.91

[58] BNWLA, 1999. A Research on Rape and Burden of Proof, Dhaka, BNWLA, p.52.

[59] BNWLA, 2010. Violence against Women in Bangladesh, 2008-2009, Dhaka, BNWLA, p.44.

[60] Osman, Ferdous Arfina, 2004. Policy Making in Bangladesh: A Study of the Health Policy Process. Banglades, Dhaka, A H Development Publishing House

[61] Jahan, Rounak and Salehin, Masudus 2006. Health Care for Rural People of Bangladesh: Overview of Some Governance Issues' in Salahuddin M. Aminuzzaman eds 'Governance and Development: Bangladesh and Regional Experiences', Dhaka, Shrabon Prokashoni

[62] Rashid ,Salim ; Savchenko, Yevgeniya ; Hossain, Najmul, 2005. 'Public Health and Governance: The Experience of Bangladesh and Ukraine’ in The Quarterly Review of Economics and Finance.45 (2005) 460-475.

[63] Article 32, Ibid; Article 3, UDHR.

[64] Article 35, Ibid; Article 5, UDHR.

[65] Article 27 and 28, Ibid; Article 7, UDHR. 